\title{
Case report: The impact of torture on mental health in the narratives of two torture survivors
}

\author{
Simone M. de la Rie, * ** Jannetta Bos, ${ }^{*}$ ** Jeroen Knipscheer, * **,***, \\ Paul A. Boelen**,***
}

\section{Key points of interest:}

- The effects of NET may be improved by tailor-made or culturally sensitive interventions that address shame, guilt, disgust and cognitions about safety, trust, power, self-esteem, and intimacy.

- Building trust and taking time to pace the therapeutic process is particularly important when treating survivors of torture.

\begin{abstract}
Introduction: Torture survivors risk developing Posttraumatic Stress Disorder (PTSD) as well as other mental health problems. This clinical case study describes the impact of torture on two survivors who were treated for their PTSD with Narrative Exposure Therapy. Method: The reports of the narratives of two torture survivors were qualitatively analyzed. It was hypothesized that torture yields overaccommodating cognitions, as well as mental defeat,
\end{abstract}

*) Foundation Centrum '45, Partner in Arq, Diemen, The Netherlands

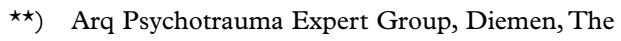
Netherlands

$\star \star \star)$ Department of Clinical Psychology, Utrecht University, Utrecht, The Netherlands which in turn, are related to severity of psychological complaints. Results: Both patients have experienced an accumulation of traumatic events. The psychological and physical torture they experienced lead to increased anticipation anxiety, loss of control and feelings of hopelessness, as well as overaccommodating cognitions regarding self and others. Conclusions: Cognitions, culture and beliefs, as well as issues of confidence and a more long-term perspective affect therapeutic work. Building trust, pacing the therapeutic process, and applying tailor-made interventions that focus on cognitions regarding self-esteem, trust in relationships, as well as safety and control are warranted.

Keywords: Refugees, torture, PTSD, trauma, narrative exposure therapy

\section{Introduction}

It was so frightening to hear the footsteps

from the guards in the corridor. What

would happen? Who would be selected? We

all shivered at the moment we heard these

footsteps and the key turning in the lock.

The account of Ahmed, a 40-year-old man from an Arab country in the Middle East, on his traumatic experiences in prison, is only one example of the horrific events recurring in the nightmares and intrusive memories that torture survivors need to deal 
with everyday. Torture ${ }^{1}$ is found to have a long-lasting effect on physical, psychological, and social areas of life. Physical as well as psychological symptoms are documented (Peel Lubell, \& Beynon 2005; Quiroga \& Jaranson, 2005; Rasmussen, 2006; Skylv, 1992). The most common mental health disorders documented as an effect of torture were posttraumatic stress disorder (PTSD) and depression, which often co-occur (Nickerson, Schick, Schnyder, Bryant, \& Morina, 2017).

Torture survivors are at an increased risk of a shattered sense of control and cognitive understanding about the self and others. Several studies have shown that when the event was perceived as uncontrollable, mental defeat (i.e. perceived loss of oneself as an autonomous person) during trauma may inflate symptom severity (Ehlers, Clarck, Dunmore, Jaycox, Meadows \& Foa et al., 1998, Ehlers \& Clark, 2000; Wilker, Kleim, Geiling, Pfeiffer, Elbert, \& Kolassa, 2017). In a study on traumatized women, Iverson et al. (2015) stated that assimilated or overaccommodated thoughts regarding safety, trust, power, esteem, and intimacy as opposed to realistic, "accommodated" thoughts, may interfere with recovery from treatment. Assimilation refers to hindsight bias, selfblame, undoing, minimizing, and denial of the event. Overaccommodation refers to modifying one's beliefs in such a way that overgeneralizations emerge, e.g. about the self (e.g., "I am a worthless person"), others (e.g., "No one can ever be trusted"), and the world (e.g., "The world is a dreadful place"). Torture may induce these types of cognitions

1 Following the definition of torture from Article 1 of the United Nations Convention Against Torture and other Cruel, Inhuman or Degrading Treatment or Punishment (UNCAT, 1984). in individuals as it deliberately attempts to "break someone's will" (Perez-Sales, 2017a). The fear- and helplessness-inducing effects of captivity determines the perceived severity of torture and psychological damage in detainees (Başoğlu et al., 2009; 2017).

\section{Treatment}

Torture survivors benefit from treatment only moderately (Patel, Kellezi, \& Williams, 2014; Perez-Sales, 2017b). A promising type of treatment is Narrative Exposure Therapy (NET). NET is an evidencebased, short-term intervention for trauma victims, designed for use in patients from all cultural backgrounds, in particular people who experienced multiple or complex traumatic events (Gwozdziewycz \& Mehl-Madrona, 2013; Lambert \& Alhassoon, 2015; Robjant \& Fazel, 2010; Schauer, Neuner, \& Elbert, 2011). During NET, therapist and patient collaboratively develop a narrative of the patient's life by identifying the most meaningful (positive and negative) life events, symbolized by "flowers" and "stones", respectively. The therapist supports the patient in constructing a chronological narrative of his/ her whole life. Exposure to each traumatic event in a chronological order aims to reconnect fragmented traumatic memories with the autobiographical memory in order to diminish trauma related complaints (Schauer, Neuner \& Elbert, 2011). All trauma-related sessions are documented in a written narrative which is handed to the patient at the end of treatment.

\section{Aims}

The current study examines the narratives of two torture survivors who underwent NET. This intervention was offered as an individual therapy embedded in a phased day treatment program for refugees (Figure 1). Their trauma 
Figure 1: Day treatment program for refugees, Centrum ' $45^{\star}$

\begin{tabular}{|c|c|c|c|}
\hline Time & Phase 1 (4 months) & Phase 2 (4 months) & Phase 3 (4 months) \\
\hline 10.00 & \multicolumn{3}{|c|}{ Welcome } \\
\hline 10.15 & $\begin{array}{c}\text { Group } \\
\text { Psychotherapy }\end{array}$ & Creative Therapy & Psychomotor Therapy \\
\hline 11.30 & $\begin{array}{c}\text { Creative Therapy/ } \\
\text { Psychomotor Therapy }\end{array}$ & $\begin{array}{c}\text { Narrative Exposure } \\
\text { Therapy }\end{array}$ & Societal Orientation \\
\hline 12.45 & \multicolumn{3}{|c|}{ Lunch } \\
\hline 13.15 & Sociotherapy & Psychomotor Therapy & Consultation Hour \\
\hline 14.30 & Consultation Hour & Consultation Hour & \\
\hline & $\begin{array}{l}\text { up-based, phase } \\
\& 3 \text { combined }\end{array}$ & $\begin{array}{l}\text { Group-based, separate } \\
\text { for each phase }\end{array}$ & Individual \\
\hline
\end{tabular}

\begin{abstract}
*The day treatment program for refugees was developed by the first author in collaboration with the multidisciplinary team as a phased-based day treatment; each phase having a duration of four months. The first phase focuses on building trust, enhancing understanding of the complaints and improving coping, emotion regulation, and sleeping. The second phase focuses on processing the traumatic memories, by means of individual NET. The third phase focuses on personal and societal rehabilitation. Throughout the entire program, patients can consult any of the other practitioners (psychiatrist, psychotherapist, social worker, socio-therapist, creative therapist, psychomotor therapist) when needed.
\end{abstract}

history, the appraisal of torture experiences, and their impact on perceived mental health are examined by labelling the cognitions as being either accommodating, assimilating, over accommodating cognitions or mental defeat. We hypothesized that torture yields over-accommodating cognitions, as well as mental defeat, which in turn, are related to the severity of psychological complaints.

\section{Methods}

Assessment

At intake, criteria from the DSM 5

(Diagnostic and Statistical Manual of Mental Disorders) were assessed. The ClinicianAdministered PTSD Scale (CAPS) - a clinician rated interview-was used to assess the severity of PTSD symptoms before and after NET (Weathers et al., 2017).

Global Assessment of Functioning (GAF) was rated by the clinician (not the NET therapist) before and after NET. The score reflects an individual's occupational, psychological, and social functioning on a continuum ranging from poor to excellent functioning (Startup, Jackson, \& Bendix, 2002).

\section{Analysis}

The therapist actively asks for cognitions and emotions in response to life threatening situations as part of exposure sessions of NET. The therapist asks about cognitions "back then" and "here and now. "A report is written of each session which results in a reconstruction of the life history of the patient at the end of treatment. The NET reports of two torture survivors are analyzed. Their cognitions-which are the sections which are not italicized in the descriptions below-are, when possible, labelled as being either assimilating, 
accommodating, over-accommodating cognitions or mental defeat.

\section{Results}

\section{The narratives of Ahmed and Morteza²}

The case of Ahmed

Ahmed is a 40-year-old Arab-speaking patient originating from a Middle Eastern country, who fled to the Netherlands when he was 30 years old. At intake he reports that he is suffering from posttraumatic stress and severe depressive symptoms. He also reports somatic complaints, his body hurts; especially his hands, feet and shoulders for which he has needed medical treatment. $\mathrm{He}$ has no job and avoids contact with other people as much as possible.

As a child he felt rejected by his mother. He reports bad memories of his childhood. As an adult he has been imprisoned for several years because of political activities. He fled the country as soon as he was released from prison, but the memories are recurring in his nightmares or in broad daylight. His asylum procedure is an ongoing stress factor in his life. He is diagnosed with PTSD and Major Depressive Disorder (MDD). His score on the CAPS before NET is 46 . His GAF score is 51 .

Treatment process: Ahmed participates in the day treatment program (Figure 1). $\mathrm{He}$ is reluctant to share anything, but participates in group therapies when invited. He builds trust in the therapist whom he already got to know before the start of the day treatment program. At phase 2 he starts with NET. He refers to five periods in his life in which he

2 Written consent concerning the narrative has been obtained from both patients. The narratives of the torture survivors are anonymized-i.e. names have been changed. has experienced severe and multiple traumas. $\mathrm{He}$ is able to discuss these events in detail with the therapist and to complete NET, although treatment duration exceeds the time scheduled.

Ahmed's narrative on torture: The fourth period in the life of Ahmed in which he has experienced multiple trauma, was during his imprisonment, as follows: ${ }^{3}$

"After my arrest I had to follow them into a small room, somewhere down below. The walls were thin. I could hear other people screaming. They started questioning me. I had no clothes on. They beat me. They used an electric wire. They hit me on my head, legs, hands, back, stomach, and genitals. I was tied up on a chair, blindfolded. After every answer, they were hitting me. I thought: 'I will die'. I smelled my flesh; it was burning because of the electric wire. I felt nauseous. I lost consciousness. Afterwards they threw me in a bath with very cold water. That was also hurting me a lot. I thought that I would drown. I still have a lot of scars on my body. They hanged me for 7-8 hours, with my legs upward and my head down. That was so difficult and very painful. I was so terribly scared. They were laughing. I was blindfolded and taken to a secret prison."

"Most people with whom I shared the cell were tortured. The torturing lasted more than a year. Sometimes one person was torturing me, another time 3 or 5 men. One day they chose me, the other day one of my fellows. It was so frightening to hear the footsteps from the guards in the corridor. What would happen? Who would be chosen? We all shivered at the moment we heard these footsteps and the key turning in the lock. It was dark in the cell. We were

3 Cognitions are in normal font. 
with many prisoners in one cell. I saw their injuries. Some never returned. During the torturing, legs, and arms could be broken. They broke my wrist. A lot of people died, due to the beating or the electricity, or because they fell ill, or were not treated for their diabetes, their heart disease. People also died due to the very bad food and the hunger. Sometimes the guards were quiet, sometimes not, depending on the amount of alcohol they had been drinking. We were all punished when someone talked too loudly. Then we were chased out of our cell and we had to stand in the hall for hours in our underwear. I felt so tired, I could hardly stand on my feet. I had to prevent that I would collapse. Collapsing meant that the beating would start again."

"I knew they could do things like this. The people who did this to us were drinking a lot of alcohol. I could smell it. They were also using drugs. I was blindfolded. They were with three to five people. One was lashing my back. The others were pushing me to the wall. They pushed me down. I am often thinking: 'I want to die' when this memory is coming up. I feel disgusted. (Note from therapist: at this point of the story patient can't sit, is jumping up and restless. He wants to vomit. Sweat is all over his face. He is trembling all over.) They raped me, one by one. They are laughing loudly. I could smell his body, the alcohol. It was so painful. I could only think: 'I want to die' I still can feel these people inside me. I feel dirty until now. Some people killed themselves. They hanged themselves. I survived. I don't know why.”

The completion of NET: After NET was completed, other complaints were aggravated due to current life stressors related to the asylum procedure. Additional treatment was offered to support Ahmed in dealing with these stressors. The CAPS score decreased, albeit, marginally, from 46 to 45 and the GAF score from 51 to 45 .

\section{The case of Morteza}

Morteza is a 48 -year-old man, born in Teheran, Iran. At intake he reports severe PTSD complaints, having recurrent nightmares and flashbacks of his imprisonment in Iran. He suffers from intrusions: thoughts, images and scents. He has problems falling asleep, and he ruminates a lot. He has problems with concentration, anger outbursts, and avoids reminders of the past. $\mathrm{He}$ also reports severe somatic complaints, chronic pain in chest and shoulders, recurrent headaches. He failed to finish education in the Netherlands and was never able to work. He is currently living alone in a small apartment, after having wandered on the streets for years, using drugs. In his childhood he experienced multiple traumatic experiences during the Iran-Iraq war. He managed to finish high school education and before his imprisonment he was a university student. He was arrested because of political activities at university four times. He escaped the fourth time and fled the country. $\mathrm{He}$ is also feeling depressed, detached and isolated. $\mathrm{He}$ is diagnosed with PTSD and MDD. The severity of his PTSD complaints as assessed by CAPS prior to treatment was 48 . His GAF score was 45 .

Narrative Exposure Therapy: At the start of the day treatment program Morteza is reluctant to enter treatment. He fears the idea of talking about his past experiences which he has avoided so far His coping skills to handle his emotions are not sufficient and during Phase 1 of the day care treatment program - prior to the NET - the focus was 
on handling these emotions. No-show is high. Nevertheless he agrees to start NET in Phase 2 and is able to describe several traumatic events in his life line, but is very scared of saying too much. He needs time to build trust in the therapist. The process of treatment is hampered because Morteza frequently does not show up for his sessions. This has been discussed and as therapy continues he learns to trust the therapist and opens up. He discloses several other traumatic events during imprisonment which he did not dare to share before because of shame. Although treatment duration of NET is longer than expected, he is able to complete NET.

Morteza's narrative: After several childhood events have been addressed by means of exposure, he mentions that the most debilitating events were yet to come. The accounts of his experiences during imprisonment are as follows: ${ }^{4}$

"I was taken to prison and pushed into a small isolation cell. It was white, the walls were filthy and written on. There was a small window through which I could talk with guards. I could hear others in the corridor. The first two months were the worst. I had little sleep and was taken away for questioning at unexpected moments, sometimes even in the middle of the night. The interrogators were aggressive, threatening, mean, and scolded at me. I was beaten with fists, but also with a whip. That was very painful. Sometimes they tied my hands on my back and hit me on my back, on my legs, but also on my soles. Then they forced me to walk. I felt so much pain. I cried, I shouted. Whenever they thought you'd lied, they beat you even harder. I could not do anything.

4 Cognitions are in normal font.
Now I'm afraid of the police, afraid they're going to get at me, despite knowing that's not happening here. I'm afraid people do not believe me, they think I'm lying. I feel insecure now too. The pain was bad, but what was worse was that I could think of nothing else all day long. I was constant in fear that they came to take me away again and that they would hurt me again. It was terrible. I thought, "they are worse than I ever could have imagined."

"After my first imprisonment, I was no longer the person I used to be. I often got negative thoughts that I felt ashamed of. I felt bad and worthless. I ruminated a lot and stayed at home often. After half a year I was arrested again, and I was detained for six months this second time. The first few months I was tortured a lot, once a week. You never knew when they would come. So you were always scared. I ruminated a lot. Would they come for me? When they summoned me to follow them, they blindfolded me before taking me to a room. I was scared what would happen again. Would I die? Could I keep it up? The room had white, dirty walls, filled with torture tools. Then I was afraid they would use that. These thoughts went through my mind. I was afraid to be a coward. First, they tied me to a chair. They were usually two men. Then they asked questions. They beat me, with their hands and legs, but also with a whip. They said I was lying. I was sometimes pulled up by my legs, then they hit me on the soles of the feet and forced me to walk. Or they would hang a stick under my knees and tied with my hands against each other. They hung the stick on two tables and then I waved upside down. They hit me in many places. It was unbearable. I had no control over my thoughts, they hit me all over my body, I forgot about where I was, who I was. I can still feel pain in my arms and legs. 
I could not bear it, I felt different kinds of pain. I cried and screamed because of the pain. What I found terrible was that they hung me on the ceiling with my hands in handcuffs. That was awfully painful, just electricity. In retrospect, I think I was lucky too. There were moments I thought if it continues, I'll tell everything. After a few months, they stopped, they knew everything and we were brought to court."

"The fourth time I was arrested and was in prison was the worst of all. It was a tough time, many people were executed. The tortures were violent, many people started talking. When the guards discovered that I had lied, they got very angry and the torture aggravated. They threatened me with everything, with rape, with execution. They said I was dirty, worthless. I was afraid, feeling little. I thought, I'll never come out, I'll die. I felt worthless. Life is nothing anymore, many people were killed. I expected to die. Everything could happen. During earlier imprisonments the rules were more clear: they finished torturing when they assumed they had all the information they needed. But now there were guards who continued with torture and seemed to enjoy the pain. I felt hate, but then at some point I thought: it's over. I had no control whatsoever. I gave up. Now I have sometimes the same feeling, as if everything is hopeless and I feel worthless."

"But the worst of the worst torture is rape. I can not say or believe this has happened, but I heard a lot of others. During the torture I often felt unconscious. One day I was beaten and threatened. I fell unconscious. There were three men. A stranger grabbed me by the arm and pulled me to the ground. I was in a room, the light was dimmed. I laid on the ground. The ground was cold and I sensed the smell of earth. I once again fell unconscious. I only have patches of memory. When I woke up I felt worthless and saw no future. I was afraid and wanted to escape."

The completion of NET: At the last session of NET he feels he has been able to discuss his life in more detail than ever before. However, several comorbid complaints remain. His CAPS score after NET is 38 and his GAF score is 50 . Although he felt some improvement in daily functioning and less overwhelmed by flashbacks, several complaints remained. He has been referred for further treatment for his other complaints.

\section{Discussion}

The narratives of Ahmed and Morteza illustrate the tremendous psychological, physical, and social toll of torture for individuals and the long-lasting impact.

\section{Psychological torture}

In their narratives, both Ahmed and Morteza described how they experienced a lack of control. The unpredictability of the experiences, hearing other people being tortured or never seeing them return to their cell induced fear and contributed to their hopelessness, and later on, in the loss of selfworth-most evident in the story of Morteza. Psychological torture during captivity induced a sense of fear and helplessness, as stated by Başoğlu (2009). This psychological torture appears to be detrimental for the ability to cope with these overwhelming experiences. The constant threat that torture could be repeated reinforced the impact of the memories. The accounts of both Ahmed and Morteza refer to anticipation anxiety, a constant free-floating anxiety while in prison due the process of dehumanization and humiliation. The uncertainty and unpredictability aggravated the anxiety and 
resulted in a generalized free-floating anxiety, even up to the present as if these events could happen again at any time. These anxious expectations are related to the severity of the anxiety complaints.

\section{The appraisal of torture events}

The cognitions regarding the torture events of both Ahmed and Morteza revealed that over-accommodating thoughts are provoked by both physical and psychological torture which affected their level of distress. In particularly the devaluating, stigmatizing, degrading remarks, laughing and shouting as well as the deliberate violation of culturally sensitive taboos (by means of rape), induced thoughts that you are 'a nobody' and feelings of shame, guilt and disgust. Emotions such as shame, guilt and humiliation attack dignity which can aggravate the breaking assumptions on self, the others and the world (Perez-Sales, 2017a).

Mental defeat, the complete lack of control during the traumatic event, did contribute to the belief that "everything is hopeless and there won't be a future." The analysis of the narrative of Morteza illustrates this. As he felt a total loss of control or was unable to anticipate anything that happened to him during his last imprisonment, he expected to die and felt totally demoralised and hopeless. They both at some point expected to die.

\section{Interplay of physical and psychological torture}

The interplay between physical and psychological consequences of torture was evident. Physical torture induced anxiety for pain and the physical harm was a constant reminder of the pain which reinforced anxiety. Both Ahmed and Morteza reported that daily pains trigger flashbacks about the traumatic events. Furthermore, the flashbacks are also triggering pain as was witnessed by the therapist when Ahmed recalled memories. It is important to note that a neurocognitive overlap of social and physical pain has been found (DeWall et al., 2010; Eisenberger \& Lieberman, 2005).

\section{Implications for treatment}

In the case of both Ahmed and Morteza, a constant feeling of threat and the accumulation of different type of traumatic events during captivity called for a pacing of the therapeutic process to disentangle the traumatic events as distinct "events" in order to reconstruct the narrative. At first, some "stones" were not named or even mentioned at all, because of shame. The chronological reconstruction required to take one step at a time.

Building trust within the therapeutic alliance and taking time by pacing the therapeutic process with patience was particularly important. It was important to be aware of accumulation of trauma and (the interplay of) physical and psychological harm, and the notion that shame may prevent sharing of the most painful or shameful events recurring in nightmares and flashbacks. Recalling memories once again induce feelings of shame and humiliation and the loss of dignity. The reluctance to say this and to show up at appointments at the beginning of the process can be understood as avoidance. Trust developed gradually within the therapeutic relationship, which eventually facilitated both Ahmed and Morteza to open up about even the most painful memories. An open, respectful, patient, empathic attitude of the therapist and calmness when listening to their horrific stories while validating the emotional impact of these experiences appears to be helpful in achieving a solid therapeutic alliance.

The moderate effects of NET may be improved by more tailor-made or culturally 
sensitive cognitive behavioural interventions that address shame, guilt, disgust and cognitions about safety, trust, power, selfesteem, and intimacy (Ehlers, A., Clark, D. M., Dunmore, E., Jaycox, L., Meadows, E., \& Foa, 1998, 2000; Iverson, King, Cunningham, \& Resick, 2015; Perez-Sales, 2017). Interventions that address core cognitions as those applied in schema therapy may be useful for the long-lasting impact of torture on the cognitions regarding self--I am worthless, I have no control" - and others- -No one can be trusted. People may hurt me again"-(Young, Klosko \& Weishaar, 2003). This may contribute to alleviating the symptoms, and patients may feel empowered to be more in control of their emotions while the process progresses.

Although both torture survivors were able to complete NET, learned to trust the therapist, and showed some improvements, the results were limited in terms of improvements in PTSD and GAF scores. It is remarkable that several positive changes could be observed in the patients, but not so much in terms of diminishing PTSD complaints. The ongoing asylum procedure and the fear of being sent back to his country and to be imprisoned and tortured again had a detrimental impact on Ahmed, because of which he had difficulties in benefiting from treatment.

It is important to look beyond physical and psychological symptoms, to broader adaptive functioning in terms of the individual's ability to feel confidence in their own capacities, in the predictability of the world, and the trustworthiness of the human community (Campbell, 2007; Hocking, Kennedy \& Sundram, 2015; Jaranson \& Popkin, 1998; Kirmayer, Rousseau \& Measham, 2010; Steel et al., 2009). This may help torture survivors to feel more in control of their life again in the long run.

\section{References}

American Psychiatric Association. (2013). Diagnostic and statistical manual of mental disorders (5th ed.). Washington, DC.

Başoğlu, M. (2009). A multivariate contextual analysis of torture and cruel, inhuman, and degrading treatments: Implications for an evidence-based definition of torture. American fournal of Orthopsychiatry 79 (2), 135-145. https://doi. org/10.1037/a0015681

Başoğlu, M. (Ed.). (2017). Torture and its definition in international law: An interdisciplinary approach. New York: Oxford University Press.

Campbell, T. A. (2007). Psychological assessment, diagnosis, and treatment of torture survivors: a review. Clinical Psychology Review, 27(5), 628-641. https://doi.org/10.1016/j.cpr.2007.02.003

DeWall, C. N., MacDonald, G., Webster, G. D., Masten, C. L., Baumeister, R. F., Powell, C., Eisenberger, N. I. (2010). Acetaminophen reduces social pain: Behavioral and neural evidence. Psychological Science, 21(7), 931-937. https://doi. org/10.1177/0956797610374741

Eisenberger, N. I., \& Lieberman, M. D. (2005). Why it hurts to be left out: the neurocognitive overlap between physical and social pain. In: K. D. Williams, J. P. Forgas, \& W. von Hippel (Eds.), The Social Outcast: Ostracism, Social Exclusion, Rejection, and Bullying (pp. 109-127). New York: Cambridge University Press.

Ehlers, A., \& Clark, D. M. (2000). A cognitive model of posttraumatic stress disorder. Behavior Research and Therapy, 38 (4), 319-345. https://doi. org/10.1016/S0005-7967(99)00123-0

Ehlers, A., Clark, D. M., Dunmore, E., Jaycox, L., Meadows, E., \& Foa, E. B. (1998). Predicting response to exposure treatment in PTSD: The role of mental defeat and alienation. Fournal of Traumatic Stress, 11 (3), 457-471.

Ehlers, A., Maercker, A., \& Boos, A. (2000). Posttraumatic stress disorder following political imprisonment: The role of mental defeat, alienation, and perceived permanent change. Fournal of Abnormal Psychology, 109 (1), 45-55. https://doi. org/10.1037//0021-843X.109.1.45

Gwozdziewycz, N. M. A. \& Mehl-Madrona, L. (2013). Meta-Analysis of the Use of Narrative Exposure Therapy for the Effects of Trauma Among Refugee Populations. Permanente fournal, 17 (1), 70-76. https://doi.org/10.7812/ TPP/12-058

Hocking, D. C., Kennedy, G. A., \& Sundram, S. (2015). Mental disorders in asylum seekers: The role of the refugee determination process and employment. Fournal of Nervous and Mental 
Disease, 203(1), 28-32. https://doi.org/10.1097/ NMD.0000000000000230

Iverson, K.M., King, M., Cunningham, K.C., \& Resick, P.C. (2015). Rape survivors' trauma-related beliefs before and after Cognitive processing therapy: Associations with PTSD and depression symptoms. Behaviour Research and Therapy 66, 4955. https://doi.org/10.1177/0886260515592618

Jaranson, J., \& Popkin, M. (Eds.). (1998). Caring for Victims of Torture. Washington, DC: American Psychiatric Press.

Kirmayer, L. J., Rousseau, C., \& Measham, T. (2010). Sociocultural considerations. In D. Benedek \& G. H. Wynn (Eds.), Clinical manual for the management of posttraumatic stress disorder. Washington: American Psychiatric Publishing, Inc.

Kross, E., Berman, M. G., Mischel, W., Smith, E. E., \& Wager, T. D. (2011). Social rejection shares somatosensory representations with physical pain. Proceedings of the National Academy of Sciences, 108(15), 6270-6275.

Lambert, J. E. \& Alhassoon, O. (2015). TraumaFocused Therapy for Refugees: Meta-Analytic Findings. Fournal of Counseling Psychology, 62(1), 28-37. https://doi.org/10.1037/cou0000048

Nickerson, A., Schick, M., Schnyder, U., Bryant, A.E. \& Morina, N. (2017). Comorbidity of

Posttraumatic Stress Disorder and Depression in Tortured, Treatment-Seeking Refugees. Fournal of Traumatic Stress, 30 (4), 409-415. http://dx.doi. org/10.1002/jts. 22205

Patel N., Kellezi B., \& Williams A.C.D.C. (2014). Psychological, social and welfare interventions for psychological health and well-being of torture survivors. Cochrane Database of Systematic Reviews, Issue 11. https://doi. org/10.1002/14651858.CD009317

Peel, M., Lubell, N., \& Beynon, J. (2005). Medical Investigation and Documentation of Torture. A Handbook for Health Professionals. Human Rights Center: University of Essex.

Pérez-Sales, P. (2017a). Psychological torture: Definition, evaluation and measurement. London: Routledge.

Pérez-Sales, P. (2017b). Psychotherapy for torture survivors - Suggested pathways for research. Torture, 27(1), 1-12.

Quiroga, J. \& Jaranson, J.M. (2005) Politicallymotivated torture and its survivors: A desk study review of the literature. Torture, 15,(2-3)

Rasmussen, O.V. (2006). The medical aspects of the UN Convention against Torture. Torture, 16(1), 58-64.

Schauer M, Neuner F, Elbert T. (2011). Narrative Exposure Therapy. A Short-term Intervention for Traumatic Stress Disorders after War, Terror or Tor- ture. $2^{\text {nd }}$, expanded edition, Göttingen: Hogrefe \& Huber Publishers.

Skylv, G. (1992). The physical sequelae of torture. In: Başoğlu, M. (ed), Torture and its consequences: current treatment approaches (pp 38-55). New York: Cambridge University Press.

Startup, M., Jackson, M. C., \& Bendix, S. (2002). The concurrent validity of the Global Assessment of Functioning (GAF). British fournal of Clinical Psychology, 41 (4), 417-422. https://doi. org/10.1348/014466502760387533

Steel, Z., Chey, T., Silove, D., Marnane, C., Bryant, R. A., \& van Ommeren, M. (2009). Association of torture and other potentially traumatic events with mental health outcomes among populations exposed to mass conflict and displacement: a systematic review and meta-analysis. Fournal of the American Medical Association, 302 (5), 537-549. https://doi.org/10.1001/jama.2009.1132

United Nations (1984). Convention against Torture and Other Cruel, Inhuman or Degrading Treatment or Punishment.

Weathers, F. W., Bovin, M. J., Lee, D. J., Sloan, D. M., Schnurr, P. P., Kaloupek, D. G., \& Marx, B. P. (2017). The Clinician-Administered PTSD Scale for DSM-5 (CAPS-5): Development and initial psychometric evaluation in military veterans. Psychological Assessment, 30(3), 383-395.

Wilker, S. Kleim, B., Geiling A., Pfeiffer A., Elbert, T. \& Kolassa I.T. (2017). Mental defeat and cumulative trauma experiences predict traumarelated psychopathology: Evidence from a postconflict population in Northern Uganda. Clinical Psychological Science, 5(6),974-984. https://doi. org/10.1177/2167702617719946

Young, J. E; Klosko, J. S; Weishaar, M. E. (2003). Schema therapy: a practitioner's guide. New York: Guilford Press. 